\title{
HIDDEN CAPITAL AS AN ALTERNATIVE METHOD FOR INCREASING PUNCHING SHEAR RESISTANCE OF LWAC FLAT SLABS
}

\author{
M. GOLDYN ${ }^{1}$, T. URBAN ${ }^{2}$
}

\begin{abstract}
In the paper an alternative method for increasing punching shear resistance of the flat slabs from lightweight aggregate concrete by means of hidden steel fibre reinforced capital was presented. Previous experimental studies demonstrated that the addition of steel fibres to concrete allows for increase in the punching shear resistance of flat slab. Steel fibres modify the tensile strength of concrete, which translates into increased ductility of the material. The results of the experimental investigations were presented, the aim of which was to assess the effectiveness of the proposed solution. For economic and technological reasons, a hidden capital of a height equal to half of the slabs depth was made so that the top reinforcement could be installed later. It was found that presented solution allowed to increase the load carrying capacity by about $36 \%$ with respect to the control element, made entirely of lightweight aggregate concrete.
\end{abstract}

Keywords: lightweight aggregate concrete, fibre reinforced concrete, punching shear, capital, sintered fly ash

\section{INTRODUCTION}

The column-and-slab systems are one of the most popular structural solutions, because they offer a lot of freedom by arranging the space inside the buildings. At the same time, they do not enforce increasing of the storey height in order to maintain the required usable space, as is in case of eg. slab-and-beam floor systems. The main load of flat slabs is usually self-weight. For this reason in many of the available commercial solutions (eg. Cobiax system) special unloading elements are

${ }^{1}$ PhD., Eng., Lodz University of Technology, Faculty of Civil Engineering, Architecture and Environmental Engineering, Department of Concrete Structures, al. Politechniki 6, 90-924 Łódź, e-mail: michal.goldyn@p.lodz.pl

${ }^{2}$ Prof. PhD., Eng., Lodz University of Technology, Faculty of Civil Engineering, Architecture and Environmental Engineering, Department of Concrete Structures, al. Politechniki 6, 90-924 Łódź, e-mail: tadeusz.urban@p.lodz.pl 
offered. Reducing the self-weight of the structure is particularly important in multi-storey facilities, because it allows for limiting the cross-section of load-bearing elements such as columns, walls or foundations. An alternative to costly, usually, system solutions can be lightweight aggregate concrete. The use of lightweight structural concrete of density classes D1.8 or D2.0 according to Model Code 2010 [1] allows to reduce the self-weight of the floor slab by about $5 \div 15 \%$.

Contemporary lightweight aggregate concretes (LWAC) made from artificial aggregate, generated in the process of sintering of fly ashes, are characterized by compressive strength similar to ordinary concretes. The same cannot be said, however, about tensile strength, which can be even more than two times lower than that of ordinary concrete of the same strength class. Lightweight concretes are characterized by higher brittleness and thus are more susceptible to failure resulting from shear or punching - mechanisms, in which the tensile strength of concrete is crucial. For this reason, in the existing design procedures (including EN 1992-1-1 [2], ACI 318-14 [3], Model Code 2010 [1]), the provisions for elements made of ordinary and lightweight aggregate concretes were distinguished.

Punching shear is the most important mechanism limiting load carrying capacity of the column-andslab structures. In case of floor spans typical for office buildings, it is usually necessary to use additional shear reinforcement in order to achieve desirable carrying capacity. An amendment to the Eurocode 2 [2], introduced in 2014, limited the possibility for increasing the punching shear resistance of the slabs up to $50 \%$, unless national provisions state otherwise. Alternative solutions for stirrups or bent-up bars are double-headed studs, which are one of the most effective types of punching shear reinforcement [4]. In accordance with the principles of EN 1992-1-1 [2], their use is determined in the relevant European Technical Approvals (ETA). By using double-headed studs an increase in punching shear carrying capacity up to $96 \%$ is allowed. All applicable technical approvals (including [5] $\div$ [8]), however, limit the possibility of using double-headed studs only to ordinary concrete slabs. The above limitation was for the authors of the paper the circumstance to look for an alternative solutions, allowing to increase the load carrying capacity of flat slabs from lightweight aggregate concretes without the need for increasing thickness of the slab within connection zone.

One of the ways to increase the punching shear resistance may be the introduction of a hidden capital made of higher strength concrete. Depending on the size of the capital as well as the relationship between the strengths of both concretes, two failure modes, shown in Fig. 1, can be distinguished. In the first case (Fig. 1a), a critical shear crack forms outside the capital. Load carrying capacity is then determined by the weaker slab concrete. Such a failure mode is similar as in case of the punching shear reinforced slab when the critical shear crack forms outside the area of transverse reinforcement. If the difference between capital and slab concrete strengths is lower, then the critical 
shear cracks can form at the column edge (Fig. 1b) - similar as in case of a slab made entirely of one type of concrete. Load carrying capacity is then dependent on strength of both concretes.

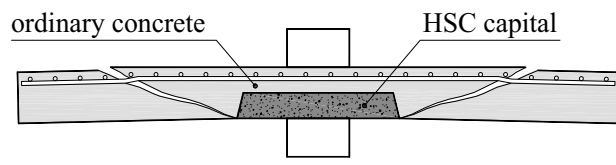

a)

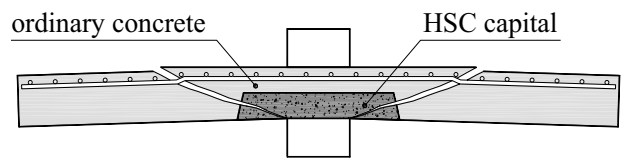

b)

Fig. 1. Possible failure modes of the slabs with hidden capitals: a) outside capital, a) within capital

\section{BACKGROUND}

In the previous works of Godycki-Ćwirko et al. [9], [10] a certain idea of casting ordinary concrete slabs with high strength concrete (HSC) capitals was presented. The investigations covered a total of 7 specimens. The variable parameters were size of the capital and the reinforcement ratio $\left(\rho_{l}=1.0\right.$ and $\left.1.5 \%\right)$. Failure of the specimens was always accompanied with the diagonal cracks crossing the capital (see Fig. 1b). An increase in the load capacity from 8 to $54 \%$ with respect to the control elements made entirely from one type of concrete, was noted.

Similar studies were conducted by Ajdukiewicz et al. [11], [12] and Hulimka [13]. These tests covered column-and-slab connection joints of ordinary concrete slabs (NSC $-f_{c}=10.7 \div 34.0 \mathrm{MPa}$ ) with built-in capitals from high strength concrete (HSC $-f_{c}=65.5 \div 90.3 \mathrm{MPa}$ ) or steel fibre reinforced high strength concrete $\left(\mathrm{SFRC}-f_{c}=82.6 \div 107.7 \mathrm{MPa}\right)$. The main variable parameters in the tests including a total of 20 elements (grouped in 5 series) were: size and shape of the capital, concrete strength of the capital, unbalanced moment transferred from the slab to the column, longitudinal reinforcement ratio and the location of the column (internal, edge or corner). The result of the tests demonstrated that approximately fivefold increase of the capital size resulted in an increase in destructive forces by about $60 \div 70 \%$. No effect of the capital shape (round or square) has been found. It was also noted that ratio of capital and slab concrete strength did not have an effect on punching shear resistance. The failure of the test specimens was accompanied by a shear cracks forming at the column edge (see Fig. 1b) with different inclinations within and outside the capital. The lack of the possibility of failure outside the capital zone (see Fig. 1a) can be justified by the insufficient stiffness of the capital with respect to the entire slab. Not without meaning might be also higher brittleness of the high strength concrete. Softening the behaviour of concrete is possible by adding steel fibres to the concrete mix. An increase in tensile strength and change to the cohesive 
failure mode has led many researchers to investigate the effect of fibre reinforced concrete on punching shear resistance of flat slabs.

One of the first works concerning use of SFRC (Steel Fibre Reinforced Concrete) were experimental investigations of Swamy and Ali [14], which covered square slabs with a side length of $1.8 \mathrm{~m}$ and a thickness of $125 \mathrm{~mm}$. The main variable parameters were: fibre content $\left(\rho_{f}=0 \div 1.2 \%\right)$, area where SFRC was placed, arrangement of the longitudinal reinforcement (with low reinforcement ratios of $\rho_{l}=0.28 \div 0.56 \%$ ) type of steel fibres (crimped, hooked or straight) and the distribution of shear reinforcement. Addition of the steel fibres resulted in a change in the inclination of critical shear crack from $24^{\circ}$ to about $19^{\circ} \div 23^{\circ}$ and increase in punching shear resistance by 23 to $42 \%$ at $\rho_{f}=0.6 \%$ and $1.2 \%$ respectively.

Encouraging results of research [14] prompted Urban [15] to carry out experimental investigations on the slabs with higher reinforcement ratios: $\rho_{l}=1.0$ and $1.25 \%$. The fibre content in the column vicinity was $\rho_{f}=0,0.6$ and $1.0 \%$. Only straight fibres with a diameter of $0.5 \mathrm{~mm}$ and a length of $49 \mathrm{~mm}$ were used. The range of SFRC zone was limited only to the immediate vicinity of the column. The dimensions of this area were determined by the anticipated shape of the punching cone (shear cracks inclined with an angle of $30^{\circ}$ ). SFRC was separated from the remaining part of the slab with steel drawn mesh (Rabitz mesh), which hindered flow of the mix during casting of concrete (see Fig. 2). Taking into account the differences in strength of concrete of subsequent specimens, the increase in the load carrying capacity could be estimated to 18 to $23 \%$ with respect to control elements without SFRC. A relatively low increase in load capacity can be explained by the use of smooth and straight fibres.

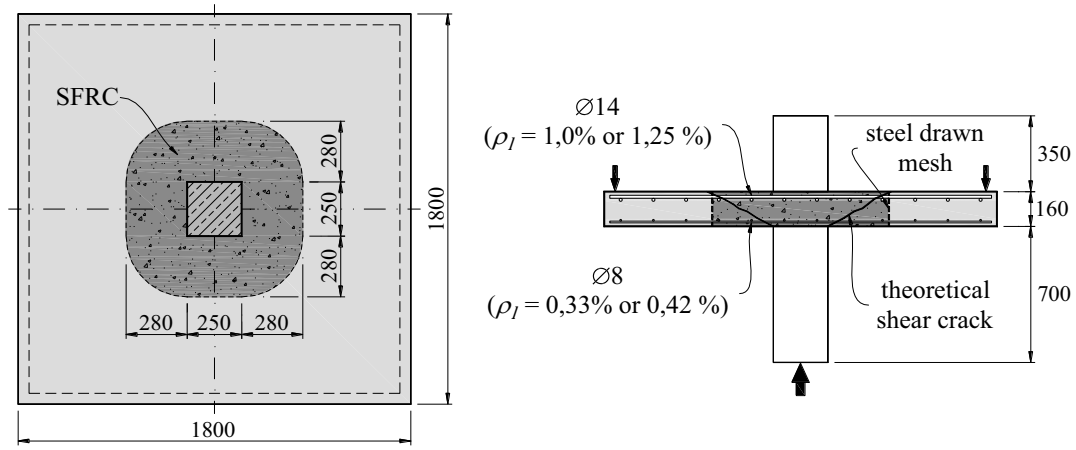

Fig. 2. Test specimens considered in [15]

The research of Alexander and Simmonds [16] showed an increase in load carrying capacity resulting from the addition of steel fibres, amounting to about 20 and $30 \%$ at the fibre content of 30 
and $60 \mathrm{~kg} / \mathrm{m}^{3}\left(\rho_{f} \sim 0.38 \%\right.$ and $\left.\sim 0.76 \%\right)$ respectively. The addition of fibres delayed the formation of cracks close to column edge which were visible at the load higher of about $20 \div 25 \%$ compared to specimens made entirely from ordinary concrete.

Theodorakopulos and Swamy [17] investigated the effect of steel fibres on punching shear capacity of lightweight aggregate concrete slabs. The research program comprised similar variable parameters to that considered in earlier studies [14]. The addition of steel fibres resulted in an almost twofold increase in the tensile strength of lightweight aggregate concrete and therefore an increase in the punching shear resistance by 30 and $43 \%$, for fibre contents of $\rho_{f}=0.5 \%$ and $1.0 \%$ respectively.

According to the results of the tests of 6 slabs with dimensions of $2300 \times 2300 \times 150 \mathrm{~mm}$ and reinforcement ratio $\rho_{l} \approx 1.06 \%$ McHarg et al. [18] formulated a general conclusion that the presence of fibres with a content of $\rho_{f}=0.5 \%$ within the support zone fundamentally changes the behaviour of the column-slab connection joint. An increase in the punching shear resistance $(26 \div 38 \%)$ and ductility, higher stiffness after cracking and the limitation of crack width at the service load level were stated. Casting SFRC only in the cover layer limited crack widths and affected slightly load carrying capacity of the specimens. According to the authors, the conclusion regarding the increase in the load capacity by $38 \%$ as a result of steel fibres addition seems to be too optimistic, because it does not account difference in strength of ordinary and fibre reinforced concrete, which was about 11.5 MPa. In the studies of Cheng and Parra-Montesinos [19], the effects of: fibre shape (hooked, twisted), fibre strength, fibre content $\left(\rho_{f}=1.0\right.$ or $\left.1.5 \%\right)$ and longitudinal reinforcement ratio $\left(\rho_{l}=0.56\right.$ or $0.83 \%$ ), were considered. Hooked fibres proved to be the most effective. At the same fibre content $\left(\rho_{f}=1.5 \%\right)$, standardized punching shear resistances (taking into account differences in the concrete strength) of SFRC slabs were about $10 \%$ and $50 \div 60 \%$ higher with respect to control specimens. Cheng and Parra-Montesinos stated that limiting the use of SFRC to the support zone only (at the distance of $\sim 2 h$ from the column edge) is sufficient to increase the punching shear resistance. However, this change proved to be insignificant when taking into account standardized loads, and was about $10 \div 20 \%$ compared to $50 \div 60 \%$ increase in case of slabs made entirely of SFRC with the same fibre content. In case of elements with higher reinforcement ratios $\left(\rho_{l}=0.83 \%\right)$, the addition of steel fibres resulted in change in failure mode and yielding of the part of the longitudinal reinforcement. Cheng and Parra-Montesinos [20] investigated also the effect of SFRC on the behavior of column-and-slab connections under seismic conditions. The results of these studies allowed to make a general statement that steel fibre reinforcement is effective in increasing punching shear resistance and deformation capacity of slab-and-column connections under combined gravity load and lateral displacement reversals. 
Nguyen-Minh et al. [21] conducted tests on 12 square slabs made in a scale. The varied dimensions of the specimens allowed for considering their slenderness $1 / d$ in addition to the effect of the steel fibre content $\left(0,30,40\right.$ and $\left.60 \mathrm{~kg} / \mathrm{m}^{3}\right)$. The addition of steel fibres increased the punching shear resistance from 16 to even $40 \%$, depending on the fibre content as well as slab slenderness. The authors of these studies have found that the shape and aspect ratio of the steel fibres are very important factors that should be taken into account in punching shear analyses of SFRC slabs.

In the paper of Gouveia et al. [22] the punching shear of SFRC slabs was considered. The main variable parameter was steel fibres content $\left(\rho_{f}=0 \div 1.25 \%\right)$. A significant increase in the punching shear resistance by $56 \div 64 \%$ was recorded only in case of specimens made from SFRC with fibre content $\rho_{f}>0.75 \%$ and addition of a plasticizer. The steel fibres in a lower amount $\left(\rho_{f}=0.5 \%\right)$ did not change the tensile strength of concrete and thus the load carrying capacity of the specimens. A comparative study in the light of Critical Shear Crack Theory (CSCT) [23] and Model Code 2010 [1] demonstrated that the design procedures were in line with the test results however more conservative results were obtained for slabs with higher fibre content.

Research of Gouveia et al. presented in [24] concerned slabs with a steel fibres content $\rho_{f}=0,1.0$ and $1.5 \%$. Two different longitudinal reinforcement ratios were considered: $\rho_{l}=0.75$ and $1.50 \%$. It was found that stiffness of the slabs was dependent to a higher extent on the longitudinal reinforcement than the content of steel fibres. The addition of steel fibres $\left(\rho_{f}=1.0 \%\right)$ resulted in an increase in punching shear resistance by $62 \%$ compared to control specimen from ordinary concrete (with $\rho_{l}=0.75 \%$ ). In case of specimens with a higher reinforcement ratio $\left(\rho_{l}=1.5 \%\right)$, the increase in the steel fibres content to $1.0 \%$ or $1.5 \%$ resulted in an increase in the ultimate load by $42 \%$ and $48 \%$ respectively. The efficiency of steel fibres was thus higher in elements characterized by lower reinforcement ratio.

Summarizing the presented studies it can be concluded that solutions consisting in applying in the connection zone HSC hidden capitals or casting SFRC have the same limitations as exist by applying shear reinforcement.

\section{EXPERIMENTAL INVESTIGATIONS}

The presented study was a continuation of previous experimental investigations concerning punching shear of flat slabs from LWAC, discussed in [25], [26]. Two elements of a real size, representing the connection zone of a $0.2 \mathrm{~m}$ thick floor slab with a span length of approximately $5.0 \mathrm{~m}$, were made. The specimens had the same dimensions in a plane of $2400 \times 2400 \mathrm{~mm}$ and a thickness of $200 \mathrm{~mm}$. The slab was connected at the bottom and at the top with column stubs with a cross-section of 
$250 \times 250 \mathrm{~mm}$ and a height of $150 \mathrm{~mm}$, made from ordinary concrete. The element LC-1.23-0bis was made entirely from lightweight aggregate concrete and constituted a control specimen. In the second model LCF-1.23/0.65 a hidden capital from SFRC was casted. The capital was supposed to be an alternative way to increase punching shear resistance against shear reinforcement - stirrups difficult in practical application and double-headed studs not anticipated by the European Technical Approvals (ETA) for use in LWAC slabs. The proposed solution was intended to use for monolithic technology. In Figure 3 the schematic process of casting floor slab with hidden SFRC capital was presented.

a)

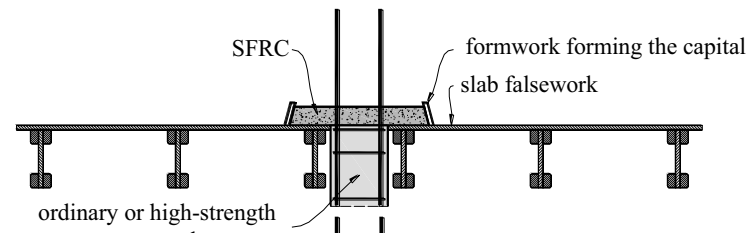

b)

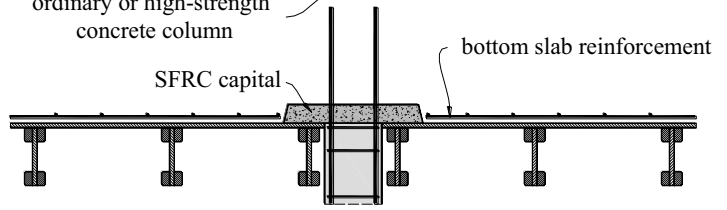

c)

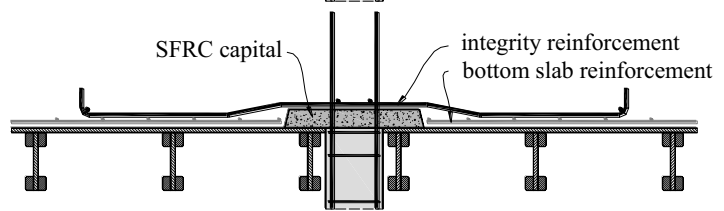

d)

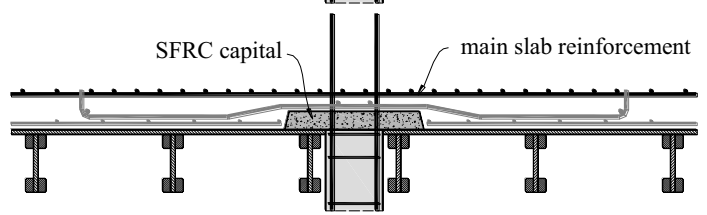

e)

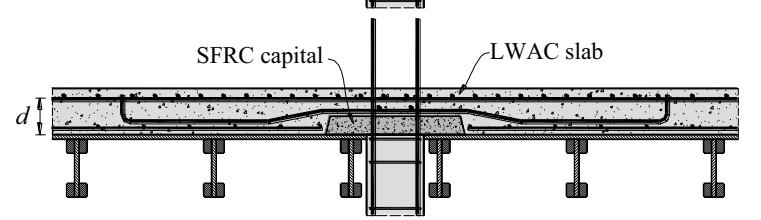

Fig. 3. Casting of the floor slab with hidden SFRC capital: a) casting of the capital, b) placing of the bottom reinforcement, c) assembling the integrity reinforcement (internal tying system), d) placing of the top (main) reinforcement, e) casting the slab with LWAC

Casting of the control specimen (LC-1.23-0 bis) was started after completing whole reinforcement and placing it into the mold. In case of the LCF-1.23/0.65 model, before casting of the slab concrete, it was necessary to make a SFRC capital, which consisted of the following steps: placing the capital forming mold, filling the mold with SFRC, preparing bottom reinforcement, removing 
the capital formwork, completing the bottom reinforcement in the form of bent-up bars, placing main (top) reinforcement and casting the specimen with LWAC. The octagonal SFRC capital has $650 \times 650 \mathrm{~mm}$ dimensions in a plane and a thickness of $100 \mathrm{~mm}$.

\subsection{Properties OF CONCRETE}

Fibre reinforced concrete was prepared on site in a laboratory mixer with a capacity of $150 \mathrm{dm}^{3}$. The composition of concrete with target strength class C70/85 was shown in Table 1. Bekaert DRAMIX 3D $65 / 35$ BG fibres with a length $l_{f}=35 \mathrm{~mm}$ and diameter $D_{f}=0.55 \mathrm{~mm}$ (aspect ratio $\lambda_{f}=65$ ), made of steel with a tensile strength of $f_{u}=1345 \mathrm{MPa}$ (manufacturer's data), were used in the mix. The fibres were fed gradually during the wet mixing of the ingredients. Due to the lower workability of the mix observed during the fibre dosing, it was necessary to increase the addition of the superplasticizer. The addition of fibres was discontinued at a content of about $0.65 \%$. Further addition was associated with the risk of reducing mix workability due to balling of the fibres.

Table 1. Recipe of steel fibre reinforced concrete (SFRC)

\begin{tabular}{|c|c|c|c|c|c|c|c|}
\hline Ingredient & $\begin{array}{c}\text { Cement } \\
\text { CEM I 42,5R }\end{array}$ & $\begin{array}{c}\text { sand } \\
0-2 \mathrm{~mm}\end{array}$ & $\begin{array}{c}\text { crushed } \\
\text { granite } \\
2-8 \mathrm{~mm}\end{array}$ & $\begin{array}{c}\text { plasticizer } \\
\text { ViscoCrete-3 }\end{array}$ & $\begin{array}{c}\text { micro silica } \\
\text { fume }\end{array}$ & water & steel fibres \\
\hline Content per $1 \mathrm{~m}^{3}$ & $540 \mathrm{~kg}$ & $727 \mathrm{~kg}$ & $889 \mathrm{~kg}$ & $\begin{array}{c}6,30 \mathrm{dm}^{3} \\
(1.25 \% \mathrm{~m} . \mathrm{c} .)\end{array}$ & $40 \mathrm{~kg}$ & $170 \mathrm{dm}^{3}$ & $\begin{array}{c}51 \mathrm{~kg} \\
(0.65 \%)\end{array}$ \\
\hline
\end{tabular}

The slabs were made of lightweight aggregate concrete with target strength class LC30/33. The Portland cement CEM I $52.5 \mathrm{~N}$, natural sand with grain size $(0-2 \mathrm{~mm})$ and lightweight aggregate 4-8 $\mathrm{mm}$ were used for concrete mix. The lightweight aggregate CERTYD was the product of the sintering process of fly ash from electrostatic precipitators and ash-slag mixture from wet furnace waste removal of hard coal combustion in boilers of a combined heat and power plant. The bulk density of the aggregate fraction $4-8 \mathrm{~mm}$ was about $700 \mathrm{~kg} / \mathrm{m}^{3}$. During casting and compacting of the concrete mix no problems related to aggregate segregation were observed. The concrete recipe is given in Table 2. The elements were made from two concrete mix supplies, which resulted in some difference in strength.

Table 2. Recipe of lightweight aggregate concrete LC30/33

\begin{tabular}{|c|c|c|c|c|c|c|c|c|}
\hline Ingredient & $\begin{array}{c}\text { Cement } \\
\text { CEM } \\
\text { I } 52,5 \mathrm{~N}\end{array}$ & $\begin{array}{c}\text { sand } \\
0-2 \mathrm{~mm}\end{array}$ & $\begin{array}{c}\text { CERTYD } \\
4-8 \mathrm{~mm}\end{array}$ & fly ash & $\begin{array}{c}\text { Master } \\
\text { Sky } 686\end{array}$ & $\begin{array}{c}\text { plasticizer } \\
\text { BV } 18\end{array}$ & $\begin{array}{c}\text { Zeolite } \\
\text { ZeoBau50 }\end{array}$ & water \\
\hline Content per $1 \mathrm{~m}^{3}$ & $310 \mathrm{~kg}$ & $610 \mathrm{~kg}$ & $650 \mathrm{~kg}$ & $100 \mathrm{~kg}$ & $2.9 \mathrm{~kg}$ & $2.4 \mathrm{~kg}$ & $10 \mathrm{~kg}$ & $190 \mathrm{dm}^{3}$ \\
\hline
\end{tabular}


After casting the specimens were stored in the laboratory for approximately 3 months. Strength parameters were determined each time on the day of testing. For this purpose cylindrical samples $\varnothing 150 / 300 \mathrm{~mm}$ (compressive strength $f_{c}$ and secant modulus of elasticity $E_{c}$ ) and cubes of side length of $150 \mathrm{~mm}$ (tensile splitting strength $f_{c t, s p}$ ) were used. The results of concrete tests are summarized in Table 3. It is worth mention that despite the difference in the lightweight aggregate concrete compressive strength, there was only a slight difference (about 3\%) in tensile strength. This is a characteristic feature of lightweight aggregate concrete, in which the increase in tensile strength associated with increase in compressive strength occurs much more slowly than in ordinary concretes, what translates into higher brittleness of this material.

On the basis of the density determined after drying in the oven, lightweight aggregate concrete has been classified into density class D1.8 according to Model Code $2010[1]\left(\rho \leq 1800 \mathrm{~kg} / \mathrm{m}^{3}\right)$.

In order to assess the effect of steel fibres on the properties of a hardened concrete, concrete without addition of fibres was also tested. Similar compressive strength $\left(f_{c m}=83.1 \mathrm{MPa}\right)$ and modulus of elasticity $\left(E_{c m}=35.2 \mathrm{GPa}\right)$, however, much lower tensile splitting strength $\left(f_{c t m, s p}=3.95 \mathrm{MPa}\right)$, were obtained, what confirms the beneficial effect of steel fibres on the features of concrete.

Table 3. Properties of hardened concrete

\begin{tabular}{|c|c|c|c|c|c|c|}
\hline \multirow{2}{*}{ Specimen } & \multirow{2}{*}{ Concrete mix } & \multirow{2}{*}{$f_{c m}[\mathrm{MPa}]$} & $f_{c t m, s p}[\mathrm{MPa}]$ & $E_{c m}[\mathrm{GPa}]$ & \multicolumn{2}{|c|}{$\rho\left[\mathrm{kg} / \mathrm{m}^{3}\right]$} \\
\cline { 5 - 7 } & & & & & $(\mathrm{SSD})$ & $(\mathrm{OVD})$ \\
\hline \multirow{2}{*}{ LC-1.23/0 bis } & LWAC & $44.5(1.6 \%)$ & $3.12(2.0 \%)$ & $20.4(1.8 \%)$ & 1842 & 1788 \\
\hline \multirow{2}{*}{ LCF-1.23/0.65 } & LWAC & $52.1(1.1 \%)$ & $3.22(6.6 \%)$ & $20.6(2.3 \%)$ & 1840 & 1770 \\
\cline { 2 - 7 } & SFRC & $79.9(0.4 \%)$ & $8.57(3.5 \%)$ & $35.7(-)$ & 2367 & - \\
\hline
\end{tabular}

Concrete density: SSD - surface saturated dry, OVD - oven dry; (values in the brackets represent coefficient of variation)

\subsection{CHARACTERISTICS OF THE REINFORCEMENT}

Both models had the same main reinforcement, consisted of $\varnothing 16$ at $100 \mathrm{~mm}$ (designed longitudinal reinforcement ratio $\rho_{l}=1.23 \%$ ). The bottom reinforcement was made of $\varnothing 10$ at $150 \mathrm{~mm}$, except for the reinforcement passing through the column contour. In this place $2 \varnothing 16$ bars in both directions were used, constituting the internal tying reinforcement (against progressive collapse). Due to the method of casting the LCF-1.23/0.65 element, the integrity reinforcement was placed after execution of the SFRC capital. For this purpose two $\varnothing 16$ bent-up bars in each direction were used. Details of the reinforcement were shown in Figure 4. 
Steel grade B500C with a pronounced yield strength and high ductility was used. The $\varnothing 16$ bars were characterized by the yield strength $f_{y m}=547.7 \mathrm{MPa}$ and the tensile strength $f_{u m}=672.2 \mathrm{MPa}$.
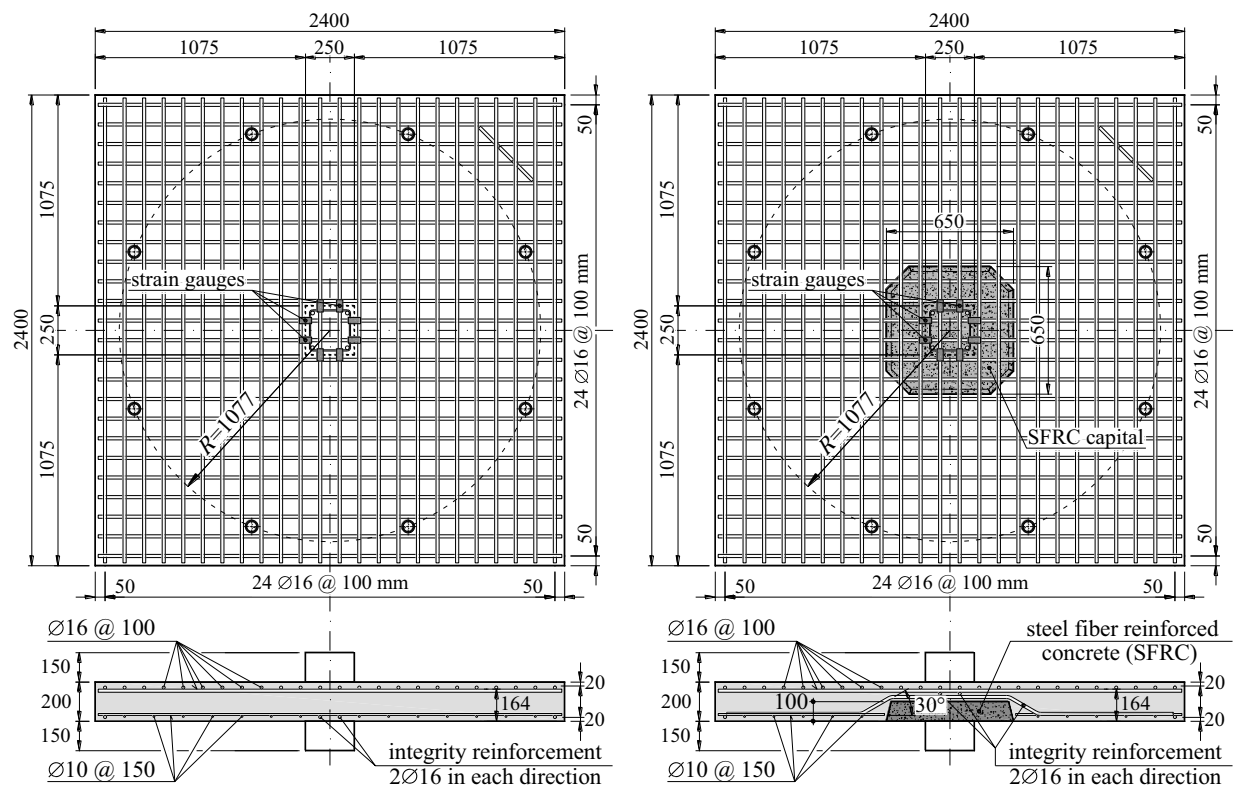

Fig. 4. Layout of the reinforcement of the test specimens

\subsection{TEST SETUP}

The tests were carried out in a test setup, enabling axially loading of the specimen - see Fig. 5. The slabs were anchored to a steel frame with 8 bolts evenly spaced around the perimeter of a circle with a diameter of $2154 \mathrm{~mm}$ (demarcating the position of zero radial bending moments in the real system). The load was applied to the column by means of 4 hydraulic jacks with a maximum total pressure of $1600 \mathrm{kN}$, connected by a steel piston ended with a ball joint. The tests were carried out under load control. The load was increased gradually by approximately $40 \mathrm{kN}$ and was held constant for about 5 minutes during which a stocktaking of the cracks as well as measurements of width of selected cracks by means of crack width gauge were provided. During the tests strains of the main reinforcement at the column edge and concrete on the compressed side of the slab were measured by means of strain gauges. The displacements were recorded by means of Linear Variable Differential Transformers (LVDT) located close to column edge and support lines. 

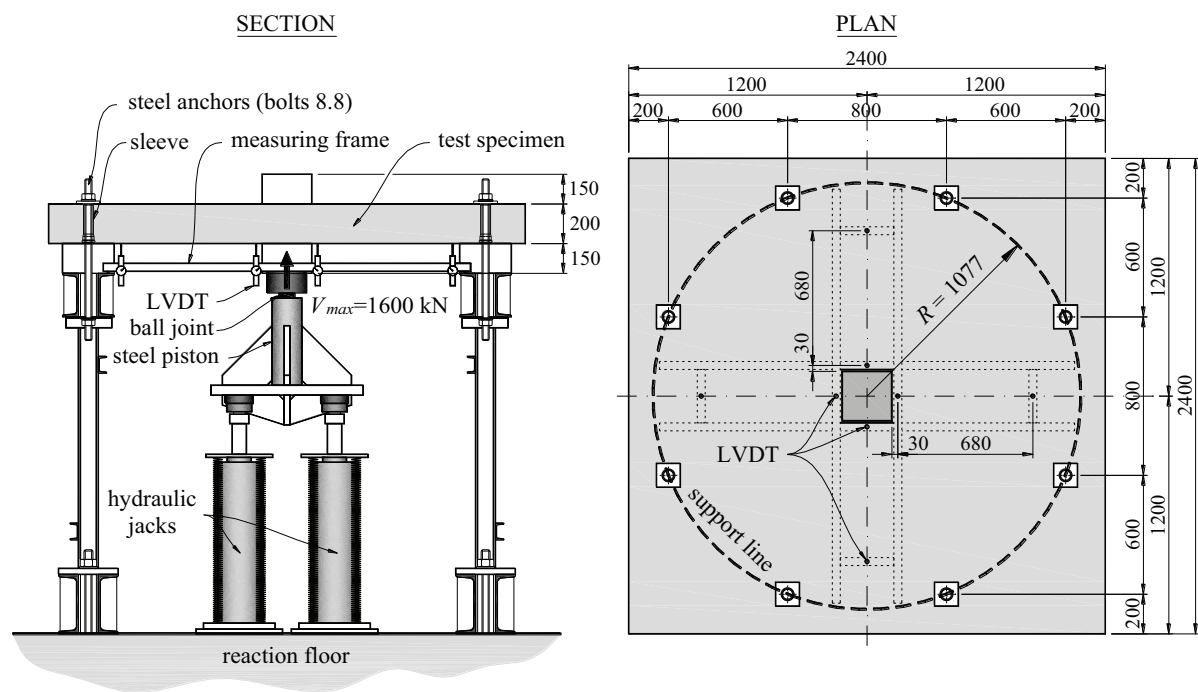

Fig. 5. Scheme of the test setup

\subsection{TEST RESULTS}

\subsubsection{STRAINS OF THE LONGITUDINAL REINFORCEMENT}

A slightly higher strain increase rate was noticed in the slab made entirely from LWAC - see Fig. 6 . Nevertheless, at the moment preceding failure of the LC-1.23-0 bis element, strains of the longitudinal reinforcement did not exceed $1.7 \div 2.0 \%$ and were therefore lower than the yield strain $\varepsilon_{y m}$. The failure mode was brittle and resulted from shear mechanism. In case of the LCF-1.23/0.65 model, the failure was preceded by yielding of the main reinforcement of the top and bottom layer at the column edge.

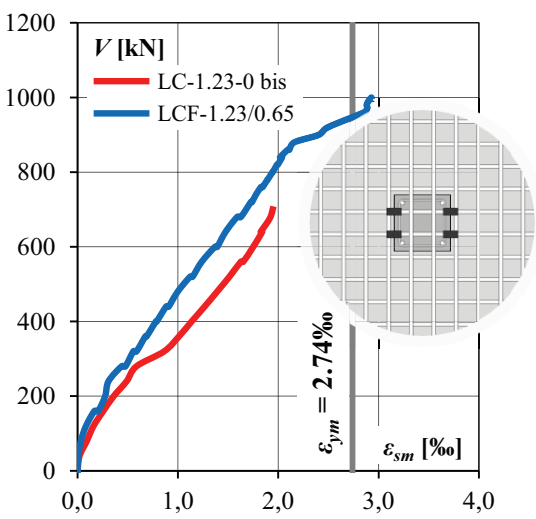

a)

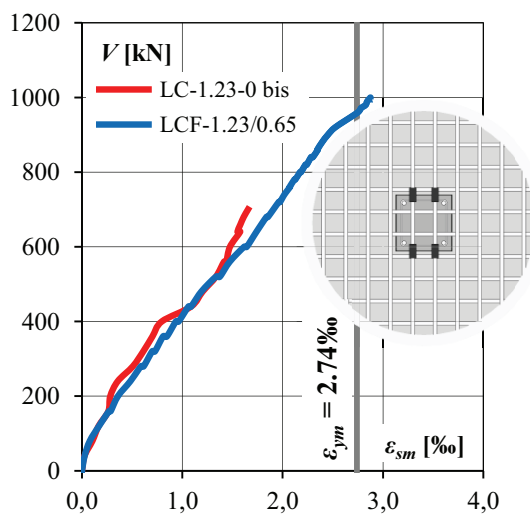

b)

Fig. 6. Comparison between mean strains of slab longitudinal reinforcement: a) bottom layer, b) top layer; 
dashed lines represent strains $\varepsilon_{y m}$ at yielding

\subsubsection{DEFLECTIONS}

In the Figure 7a the average deflections of the specimens were presented. The increase in stiffness resulting from the introduction of the SFRC capital is clearly visible. The maximum deflection $u_{\max }$ of the slab made entirely of LWAC was about $6 \mathrm{~mm}$, while $9 \mathrm{~mm}$ in case of the element with SFRC capital. In both cases, the failure was violent (brittle). The measurements of deflections of LCF-1.23/0.65 element did not indicate any change in the intensity of deformation growth, indicating approaching the flexural limit carrying capacity. After reaching the maximum load $V_{\text {exp }}=1000 \mathrm{kN}$ a significant decrease in force to about $635 \mathrm{kN}$ with the simultaneous displacement of the column by about $2 \mathrm{~mm}$ with respect to the bottom slab surface, was recorded. This should be identified with the formation of a punching cone. Until the test was interrupted, a gradual drop in force was recorded, accompanied by an increase in deformation (pushing the punching cone).

According to the LVDT measurements rotations of the slab were determined - see Fig. 7b. The lowest increase in deformation was found in the LCF-1.23/0.65 specimen with a SFRC capital. This model was also characterized by the highest rotation capacity - at the failure mean rotation $\psi=0.0121$ was about $46 \%$ higher than the maximum value registered in case of control specimen LCF-1.23-0 bis.

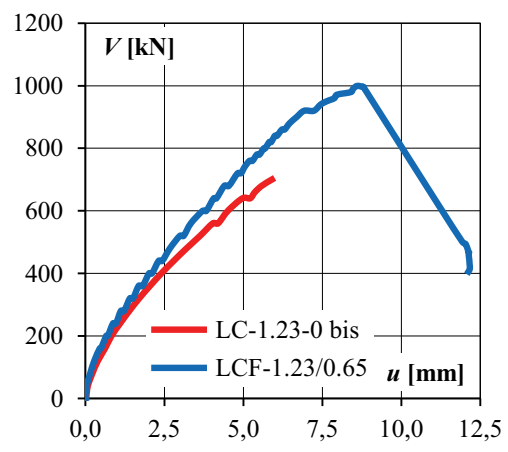

a)

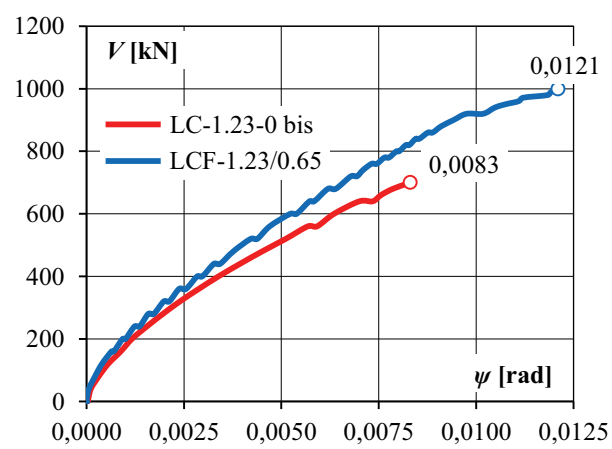

b)

Fig. 7. Comparison between: a) deflections, b) rotations of the slabs

\subsubsection{CRACKS ON THE TOP SURFACE}

In case of the element with SFRC capital, radial cracks were clearly visible in the initial phase of the test, while on the surface of the LC-1.23-0 bis model at the same load level only small cracks referring to the longitudinal reinforcement layout were found. At a load of about $40 \%$ ultimate force on the surfaces of 
both models, radial cracks were clearly visible. A further increase in load led to a development of the tangential cracks, which were mostly concentrated in the vicinity of the capital perimeter of the LCF-1.23/0.65 element. In case of the LC-1.23-0 bis model, uniform, fairly intense crack pattern was observed within the zone with a range of about $2.5 d$ from the column edge. Comparing the crack pattern after failure a clear base of the punching cone in a specimen made entirely of LWAC could be found. The outlet of the shear cracks was located at a distance of about $600 \div 700 \mathrm{~mm}$ from the column edge. In the case of the LCF-1.23/0.65 model, the contour of the cone base is noticeably closer to the support lines, which indicates a different slope of the critical shear crack - see Fig. 8.

A similar intensity of the crack width development was noticed, although at the same load level the smallest cracks were noted in case of the LCF-1.23/0.65 element with the SFRC capital. Cracks with a width of $w=0,30 \mathrm{~mm}$ (corresponding to the service load level) were noted at a load of approximately $60 \%$ and $50 \%$ of ultimate load of the control specimen and element with SFRC capital respectively. The cracks widths measured shortly before failure reached $0.4 \div 0.6 \mathrm{~mm}$ and $0.6 \div 0.8 \mathrm{~mm}$ in case of LC-1.23-0 bis and LCF-1.23/0.65 specimen, respectively.

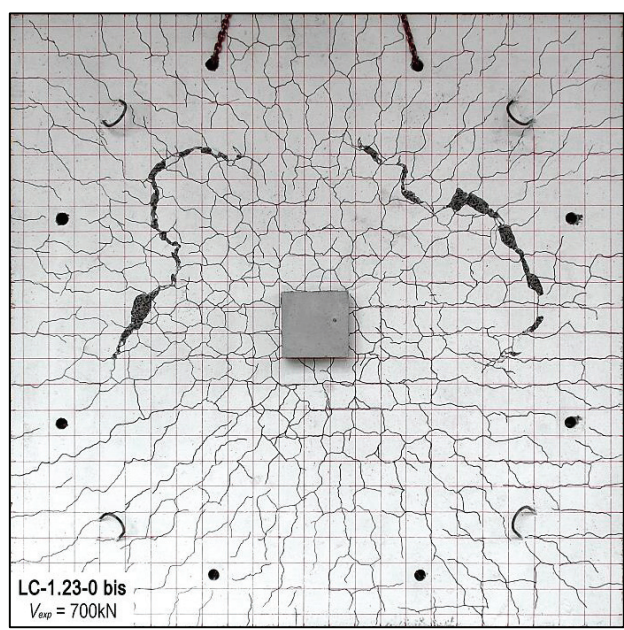

a)

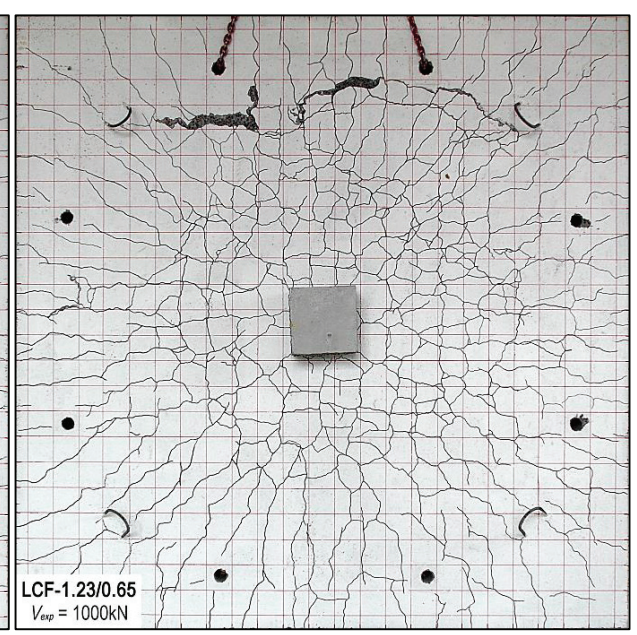

b)

Fig. 8. View of the top surface of the specimens after failure: a) LC-1.23-0 bis, b) LCF-1.23/0.65

\subsubsection{SHEAR CRACKS}

Previous observations were confirmed by the crack pattern visible in the model intersections - see Fig. 9. In the LC-1.23-0 bis specimen, the diagonal crack formed on the column edge and ran at an angle $\theta=28 \div 30^{\circ}$ towards the upper slab surface. At a plane of longitudinal reinforcement a change 
in the crack inclination to about $10^{\circ}$ was visible. The course of the cracks was then similar to that observed in the previous study [25], including slabs made of LWAC without punching shear reinforcement. In case of the LCF-1.23/0.65 model, critical shear crack also formed at the column edge, what indicated the second failure mode (cf. Fig. 1b), resulted from exceeding the strength of both concretes - LWAC and SFRC. The inclination of the diagonal crack within the SFRC capital was about $\theta=22 \div 27^{\circ}$. At the interface of both concretes a change in the inclination could be observed - the crack ran more horizontally, with an angle of approximately $\theta=12 \div 17^{\circ}$ - see Fig. 9 . Another change in the slope of the shear crack took place at the level of the main reinforcement, when its inclination dropped further to approximately $10^{\circ}$. At this point it is also worth noting, that no delamination between LWAC and SFRC, casted at different times, had been found.

a)

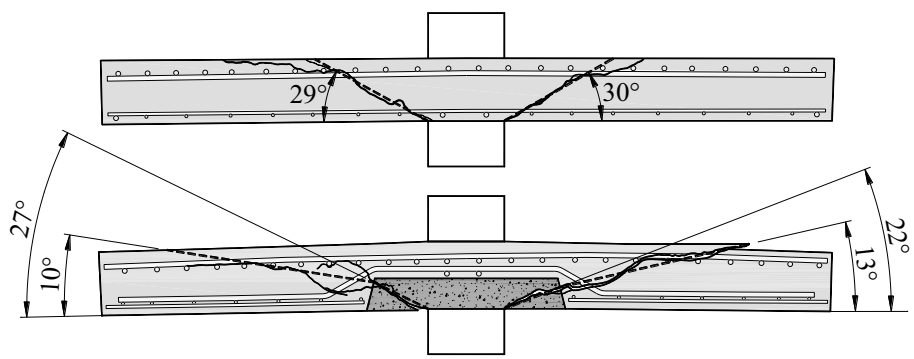

Fig. 9. Course the critical shear cracks: a) LC-1.23-0 bis, b) LCF-1.23/0.65

\subsubsection{EXPERIMENTAL LOADS}

All of the specimens failed in a violent manner, characteristic for punching. In the Table 4 the experimental loads $V_{\exp }$ were summarized. After saw-cut of the models, the actual position of the main reinforcement was determined. It differed slightly from the originally designed. For this reason, in the Table 4 the nominal $\left(d_{n o m}\right)$ as well as measured $\left(d_{a c t}\right)$ effective depths, (adopted for further analysis) were listed. Due to differences in strengths of LWA concretes, it was impossible to directly compare the experimental loads of both specimens. In order to reflect the differences in the concrete strength as well as the effective depths, standardized loads $\left(V_{\text {stand }}\right)$ were calculated according to the equation (1) (all designations with "cont" note refer to control specimen LC-1.23-0 bis):

$$
V_{\text {stand }}=V_{\exp } \sqrt[3]{\frac{\rho_{l, \text { cont }} f_{\text {lcm, cont }}}{\rho_{l} f_{\text {lcm }}}} \frac{d_{\text {act, cont }}}{d_{\text {act }}}
$$

where: 
$V_{\text {exp }}$ - experimental load of the test specimen, $d_{a c t}$ - actual effective depth of the test specimen, $f_{l c m}$ - mean value of LWAC compressive strength, $\rho_{l}$ - slab longitudinal reinforcement ratio.

Table 4. Test results and actual section properties

\begin{tabular}{|c|c|c|c|c|c|c|}
\hline Specimen & $\begin{array}{c}d_{\text {nom }} \\
{[\mathrm{mm}]}\end{array}$ & $\begin{array}{c}d_{\text {act }} \\
{[\mathrm{mm}]}\end{array}$ & $\begin{array}{c}\rho_{l} \\
{[\%]}\end{array}$ & $\begin{array}{c}f_{\text {ckm }} \\
{[\mathrm{MPa}]}\end{array}$ & $\begin{array}{c}V_{\text {exp }} \\
{[\mathrm{kN}]}\end{array}$ & $\begin{array}{c}V_{\text {stand }} \\
{[\mathrm{kN}]}\end{array}$ \\
\cline { 1 - 7 } LC-1.23-0 bis & \multirow{2}{*}{164} & 161 & 1.25 & 44.5 & 700 & - \\
\cline { 1 - 5 } LC-1.23/0.65 & 160 & 1.26 & 52.1 & 1000 & 952 \\
\hline
\end{tabular}

By comparing the standardized punching shear resistances, it can be stated that use of SFRC allowed to increase the load carrying capacity of LWAC slab by approximately $36 \%$ compared to the control specimen LC-1.23-0 bis. SFRC capital proved to be effective, despite its limited range and thickness, which was only half of the slab depth. Evidently, the effectiveness of the presented solution also resulted from the arrangement of the bottom (intergrity) reinforcement preventing the progressive collapse. Due to the shape of the reinforcement, it could act as bent-up bars, increasing the punching shear resistance - see Fig. 10.

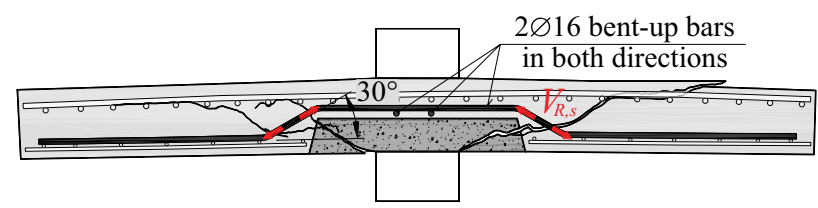

Fig. 10. Contribution of bent-up bars (integrity reinforcement) as punching shear reinforcement

The theoretical contribution of bent-up bars in punching shear resistance was estimated according to Model Code 2010 [1] principles, taking into account the experimentally determined ultimate slab rotation $\psi$. The contribution of bent-up bars was about $260 \mathrm{kN}$, which accounted for $26 \%$ of the experimental load $V_{\exp }$ of the specimen. The remaining load carrying capacity resulted from the contribution of fibre reinforced concrete capital and lightweight aggregate concrete.

\section{Conclusions}

The results of the experimental investigations demonstrated that hidden capitals can be an interesting alternative to traditional punching shear reinforcement. The proposed solution consisting in casting a SFRC capital only in within column-and-slab connection zone seems to be easy to do also on the construction site. The height of the capital in the presented study was only half of the slab depth as not to impede placing of the main and integrity reinforcement. Despite the relatively 
small capital overhang beyond the column edge $\left(l_{H} \approx 1.25 d\right)$, a significant increase in load carrying capacity was achieved - about $36 \%$ with respect to the control element. It seems that in the case of thicker slabs it would be possible to cast capitals of higher thicknesses and diameters what would allow to increase the efficiency of the proposed solution. The increase in the efficiency of the capital can also be expected by using SFRC with higher steel fibre content.

\section{ACKNOWLEDGEMENTS}

The authors would like to thank LSA sp. $\mathrm{z}$ o.o. for the support and assignation the of the lightweight aggregate free of charge. The authors would also like to express their gratitude to PhD Eng. Lukasz Krawczyk and MSc Eng. Łukasz Sowa for their help by experimental research.

\section{REFERENCES}

1. Fédération Internationale du Béton (FIB). Model Code 2010 - first complete draft, vol. 1 and 2, Fédération Internationale du Béton, Bulletin 55. Lausanne (Switzerland): 2010.

2. European Standard. EN 1992-1-1:2004/A1:2014, Design of Concrete Structures-Part 1: General Rules and Rules for Buildings (Including the Amendment A1:2014), European Committee for Standardization, Brussels, Belgium, 2004.

3. ACI Committee 318. Building code requirements for structural concrete (ACI 318-14) and commentary (ACI 318R14), Farmington Hills, American Concrete Institute, 2014.

4. J. Einpaul, F. Brantschen, M. Fernández Ruiz, A. Muttoni, "Performance of Punching Shear Reinforcement under Gravity Loading: Influence of Type and Detailing”, ACI Structural Journal 113(4):827-838, 2016.

5. European Technical Approval ETA-12/0454, HALFEN HDB shear rail: Double-headed studs as punching reinforcement, Deutsches Institut für Bautechnik, December 2012.

6. European Technical Approval ETA-13/0076, Punching reinforcement Schöck Bole: Double-headed studs as punching reinforcement for flat slabs and footings. Berlin: Deutsches Institut für Bautechnik, March 2013.

7. European Technical Approval ETA-13/0136, JORDAHL punching reinforcement JDA: Double-headed studs as punching reinforcement for flat slabs and footings. Berlin: Deutsches Institut für Bautechnik, March 2013.

8. European Technical Approval ETA-13/0151, PEIKKO PSB punching reinforcement: Double-headed studs as punching reinforcement. Berlin: Deutsches Institut für Bautechnik, March 2013.

9. T. Godycki-Ćwirko, A. Kosińska, T. Urban, "Badania eksperymentalne pewnej koncepcji wzmocnienia strefy przysłupowej" (Experimental investigations on some concept for strengthening of the support zone). XXXVIII Konferencja Naukowa KILiW PAN i KN PZITB, Krynica 1992, t. II, 139-144 (in Polish).

10. T. Godycki-Ćwirko, A. Kosińska, T Urban, „Badania eksperymentalne strefy przysłupowej stropu bezryglowego” (Experimental investigations of the support zone of the flat slab floor system). Inżynieria i Budownictwo, (4): 174-178, 1994 (in Polish).

11. A. Ajdukiewicz, J. Hulimka, A. Kliszczewicz, „Badania połączeń płyta-słup o konstrukcji zespolonej” (Experimental investigations of composite column-and-slab connections). XLIII Konferencja Naukowa KILiW PAN i KN PZITB, Krynica, t. IV, 13-18, 1997 (in Polish).

12. A. Ajdukiewicz, A. Kliszczewicz, "Application of High-Strength Concrete in Composite Skeletal Structures", 3rd International FIP/CEB/ACI Symposium on Utilization of High Strength Concrete, Norwegian Concrete Association, Lillehammer, Norway, Vol. 1, June 1993, 449-456

13. J. Hulimka, "Strefa podporowa żelbetowego stropu płaskiego o podwyższonej nośności na przebicie" (Support zone of RC flat floor of increased punching shear capacity). Wydawnictwo Politechniki Śląskiej, Gliwice, 2009 (in Polish)

14. R.N. Swamy, S.A.R. Ali, "Punching Shear Behaviour of Reinforced Slab-Column Connections Made with Steel Fibre Concrete", ACI Structural Journal 79(5):392-406, 1982.

15. T. Urban, "Badania żelbetowych złączy płytowo-słupowych $z$ dodatkiem drutu ciętego w strefie przysłupowej" (Experimental investigations of RC column-and-slab connection joints with addition of the steel-cut wire within connection zone) Inżynieria i Budownictwo 41(10): 223-228, 1984 (in Polish). 
16. S.D.B. Alexander, S.H. Simmonds, "Punching shear tests of concrete slab-column joints containing fibre reinforcement”, ACI Structural Journal 89(4):425-32, 1992.

17. D.D. Theodorakopoulos, N. Swamy, "Contribution of steel fibres to the strength characteristics of lightweight concrete slab-column connections failing in punching shear", ACI Structural Journal 90(4):342-55, 1993.

18. P.J. McHarg, W.D. Cook, D. Mitchell, Y.S. Yoon, "Benefits of concentrated slab reinforcement and steel fibres on performance of slab-column connections", ACI Structural Journal 97(2):225-34, 2000.

19. M.Y. Cheng, G.J. Parra-Montesinos, "Evaluation of steel fibre reinforcement for punching shear resistance in slab-column connections - Part I: Monotonically increased load", ACI Structural Journal 107(1):101-109, 2010.

20. M.Y. Cheng, G.J. Parra-Montesinos, "Evaluation of steel fibre reinforcement for punching shear resistance in slabcolumn connections - Part II: Lateral Displacement Reversals", ACI Structural Journal 107(1):110-118, 2010.

21. L. Nguyen-Minh, M. Rovnak, T. Tran-Quoc, "Punching shear capacity of interior SFRC slab-column connections", Journal of Structural Engineering ASCE: 613-624, 2012, doi:10.1061(ASCE)ST.1943-541x.0000497.

22. N.D. Gouveia, N.A.G. Fernandes, D.M.V. Faria, A.M.P. Ramos, V.J.G. Lúcio, "SFRC flat slabs punching behaviour - Experimental research", Composites: Part B 63:161-171, 2014, doi:10.1016/j.compositesb.2014.04.005.

23. A. Muttoni, M. Fernández Ruiz, "MC2010: The critical shear crack theory as a mechanical model for punching shear design and its application to code provisions: In: fib Bulletin 57: shear and punching shear in RC and FRC elements. Lausanne (Switzerland), 31-60, 2010.

24. N.D. Gouveia, M. Lapi, M. Orlando, D.M.V. Faria, A.M.P. Ramos, "Experimental and theoretical evaluation of punching strength of steel fibre reinforced concrete slabs", Structural Concrete 19: 217-229, 2018, doi:10.1002/suco.201700136.

25. M. Gołdyn, Ł. Krawczyk, W. Ryżyński, T. Urban, "Experimental Investigations on Punching Shear of Flat Slabs Made from Lightweight Aggregate Concrete”, Archives of Civil Engineering 44(4): 293-306, 2018, doi:10.2478/ace-2018-0058.

26. T. Urban, M. Gołdyn, Ł. Krawczyk, Ł. Sowa, "Experimental investigations on punching shear of lightweight aggregate concrete flat slabs", Engineering Structures 197, 2019, doi:10.1016/j.engstruct.2019.109371

27. M. Gołdyn, Ł. Krawczyk, T. Urban, "Punching Shear of Lightweight Aggregate Concrete Flat Slabs", In: Proceedings of International fib Congress: Better, Smarter, Stronger, Melbourne 2018; 


\section{LIST OF FIGURES AND TABLES:}

Fig. 1. Possible failure modes of the slabs with hidden capitals: a) outside capital, a) within capital

Rys. 1. Możliwe sposoby zniszczenia na przebicie płyt z ukrytymi głowicami: a) poza, b) w obrębie głowicy

Fig. 2. Test specimens considered in [15]

Rys. 2. Elementy rozważane w badaniach [15]

Fig. 3. Casting of the floor slab with hidden SFRC capital: a) casting of the capital, b) placing of the bottom reinforcement, c) assembling the integrity reinforcement (internal tying system), d) placing of the top (main) reinforcement, e) casting the slab with LWAC

Rys. 3. Kolejne etapy wykonywania płyty z ukrytą głowicą z fibrobetonu: a) formowanie głowicy, b) układanie zbrojenia dolnego, c) wykonywanie zbrojenia uciąglającego (wieńca wewnętrznego), d) układanie zbrojenia górnego (głównego), e) układanie lekkiego betonu kruszywowego

Fig. 4. Layout of the reinforcement of the test specimens

Rys. 4. Schemat zbrojenia elementów badawczych

Fig. 5. Scheme of the test setup

Rys. 5. Schemat stanowiska badawczego

Fig. 6. Comparison between mean strains of slab longitudinal reinforcement: a) bottom layer, b) top layer; dashed lines represent strains $\varepsilon_{y m}$ at yielding

Rys. 6. Porównanie średnich odkształceń zbrojenia podłużnego płyty: a) warstwa górna, b) warstwa dolna; linią przerywaną oznaczono odkształcenie wyznaczające początek uplastycznienia $\varepsilon_{y m}$

Fig. 7. Comparison between: a) deflections , b) rotations of the slabs

Rys. 7. Porównanie: a) ugięć, b) kątów obrotu płyt

Fig. 8. View of the top surface of the specimens after failure: a) LC-1.23-0 bis, b) LCF-1.23/0.65

Rys. 8. Widok górnej powierzchni modeli po zniszczeniu: a) LC-1.23-0 bis, b) LCF-1.23/0.65

Fig. 9. Course the critical shear cracks: a) LC-1.23-0 bis, b) LCF-1.23/0.65

Rys. 9. Przebieg krytycznych rys ukośnych: a) LC-1.23-0 bis, b) LCF-1.23/0.65

Fig. 10. Contribution of bent-up bars (integrity reinforcement) as punching shear reinforcement

Rys. 10. Udział prętów odgiętych (zbrojenia uciąglającego) jako zbrojenia na przebicie

Tab. 1. Recipe of steel fibre reinforced concrete (SFRC)

Tab. 1. Receptura fibrobetonu

Tab. 2. Recipe of lightweight aggregate concrete LC30/33

Tab. 2. Receptura lekkiego betonu kruszywowego klasy LC30/33

Tab. 3. Properties of hardened concrete

Tab. 3. Właściwości stwardniałego betonu

Tab. 4. Test results and actual section properties

Tab. 4. Wyniki badań i rzeczywiste parametry przekroju płyt 


\section{UKRYTA GLOWICA Z FIBROBETONU JAKO ALTERNATYWNY SPOSÓB ZWIĘKSZENIA NOŚNOŚCI} NA PRZEBICIE PLYT PLASKICH Z LEKKIEGO BETONU KRUSZYWOWEGO

Słowa kluczowe: lekki beton kruszywowy, fibrobeton, przebicie, głowica, spiekane popioły lotne

\section{STRESZCZENIE:}

Ustroje płytowo - słupowe stanowią jedno z popularniejszych rozwiązań konstrukcyjnych, ponieważ umożliwiają dużą swobodę kształtowania przestrzeni wewnątrz budynków. Dominującym obciążeniem stropów płaskich jest z reguły ciężar własny, dlatego też często dąży się do jego ograniczenia poprzez wprowadzenie elementów odciążających (np. system Cobiax) lub wykonanie płyty stropowej z lekkiego betonu kruszywowego. Przy typowych rozpiętościach stropów płaskich z reguły konieczne jest stosowanie dodatkowego zbrojenia na przebicie, które może składać się ze strzemion lub trzpieni dwugłówkowych. Możliwość stosowania pierwszego ze wspomnianych rodzajów zbrojenia została znacznie ograniczona w wyniku wprowadzenia w życie w 2014 roku poprawki do normy EN 1992-1-1. W przypadku płyt z lekkich betonów kruszywowych stanowi to istotne utrudnienie, bowiem Europejskie Aprobaty Techniczne - dokumenty, zgodnie z którymi należy projektować zastosowanie trzpieni dwugłówkowych, ograniczają zastosowanie tego rodzaju zbrojenia wyłącznie do płyt z betonu zwykłego. Powyższe ograniczenie stanowiło dla autorów artykułu przesłankę do poszukiwania alternatywnych rozwiązań, pozwalających na zwiększenie nośności na przebicie płyt płaskich z lekkich betonów kruszywowych bez konieczności ich kłopotliwego pogrubiania w strefie podporowej. Jednym z możliwych rozwiązań może być wprowadzenie ukrytej głowicy wykonanej z betonu o wyższej wytrzymałości. W zależności od rozmiaru i sztywności głowicy krytyczna rysa ukośna może formować się poza głowicą (o nośności na przebicie decyduje słabszy beton płyty) lub też może formować się na krawędzi słupa i przecinać głowicę (o nośności decyduje wówczas wytrzymałość obu betonów). W obu przypadkach należy jednak oczekiwać wyższej nośności na przebicie względem płyty wykonanej w całości z lekkiego betonu kruszywowego.

W celu oceny skuteczności ukrytej głowicy w Laboratorium Katedry Budownictwa Betonowego Wydziału Budownictwa, Architektury i Inżynierii Środowiska Politechniki Łódzkiej przeprowadzono badania niszczące elementów wykonanych $\mathrm{z}$ betonu lekkiego na kruszywie CERTYD, stanowiącym produkt spiekania popiołów lotnych. Głowica wykonana została z betonu o wysokiej wytrzymałości zbrojonego włóknami stalowymi. Dotychczasowe badania eksperymentalne wykazały bowiem, iż dodatek włókien stalowych do betonu może bardzo korzystnie wpływać na nośność płyt na przebicie, prowadząc do nawet $40 \div 60 \%$ jej wzrostu, zależnie od stopnia zbrojenia głównego. Wynika to przede wszystkim ze zwiększenia wytrzymałości betonu na rozciąganie. Włókna stalowe sprawiają jednak również, iż beton wykazuje zachowanie bardziej ciągliwe, co jest istotne w przypadku elementów wrażliwych na zniszczenie ze względu na ścinanie.

Badania obejmowały dwa modele płyt wykonanych w skali naturalnej, reprezentujące strefę podporową stropu płaskiego grubości 0,2 $\mathrm{m}$ i rozpiętości w osiach podpór około 5,0 m. Płyty charakteryzowały się jednakowymi wymiarami w rzucie $2400 \times 2400 \mathrm{~mm}$ i grubością równą $200 \mathrm{~mm}$. Jeden z elementów (LC-1.23-0 bis) wykonany został w całości z lekkiego betonu kruszywowego i stanowił model - świadek. Drugi z elementów (LCF-1.23/0.65) służył ocenie skuteczności rozważanego rozwiązania, polegającego na zastosowaniu fibrobetonu w strefie podporowej. W tym celu wykonano ukrytą głowicę z fibrobetonu o projektowanej klasie wytrzymałości C70/85 i wymiarach około $650 \times 650 \mathrm{~mm}$ oraz wysokości $100 \mathrm{~mm}$ (połowa grubości płyty) a następnie zabetonowano pozostałą część płyty. Oba modele wykonano z betonu lekkiego o projektowanej klasie wytrzymałości LC30/33. Zbrojenie główne stanowiły pręty $\varnothing 16$ rozmieszczone co $100 \mathrm{~mm}$, co przekładało się na średni stopień zbrojenia podłużnego $\rho_{l}=1,23 \%$. Wprowadzenie głowicy wymagało dodatkowych zabiegów technologicznych, polegających na: ułożeniu formy kształtującej głowicę, wypełnieniu 
głowicy fibrobetonem, przygotowaniu zbrojenia dolnego płyty, usunięciu szalunku głowicy, uzupełnieniu zbrojenia dolnego w strefie podporowej oraz ułożeniu zbrojenia górnego. Ostatni etap prac stanowiło zabetonowanie modelu LCF-1.23/0.65 przy użyciu lekkiego betonu kruszywowego.

Badania prowadzono w stanowisku umożliwiającym obciążanie elementu w sposób osiowy. Modele kotwione były do stalowej ramy stanowiska za pomocą 8 śrub rozmieszczonych równomiernie na obwodzie. Obciążenie realizowano za pomocą 4 siłowników o maksymalnym nacisku $1600 \mathrm{kN}$. W trakcie badań prowadzono pomiar odkształceń zbrojenia podłużnego na krawędzi słupa oraz betonu po stronie ściskanej a także deformacji za pomocą czujników przemieszczeń linowych. W trakcie badań stwierdzono większą intensywność narastania odkształceń zbrojenia podłużnego w elemencie wykonanym w całości z betonu lekkiego. W chwili poprzedzającej zniszczenie odkształcenia zbrojenia podłużnego nie przekraczały jednak $1,7 \div 2,0 \%$ i były niższe od odkształcenia wyznaczającego początek uplastycznienia. Zniszczenie modelu LCF-1.23/0.65 było natomiast poprzedzone uplastycznieniem zbrojenia głównego na krawędzi słupa. Zastosowanie fibrobetonu umożliwiło tym samym lepsze wykorzystanie zbrojenia głównego. Zauważono wyraźny wzrost sztywności wynikający z wprowadzenia głowicy fibrobetonowej. Przy tym samym obciążeniu rejestrowane ugięcia były nawet o około $20 \%$ mniejsze względem elementu wykonanego w całości z betonu lekkiego. Obserwowano zbliżoną intensywność rozwoju rys na górnej powierzchni płyt, aczkolwiek przy tym samym obciążeniu mniejsze szerokości rozwarcia rys odnotowano w przypadku elementu LCF-1.23/0.65 z głowicą fibrobetonową. Rysy o szerokości $w=0,30 \mathrm{~mm}$ (odpowiadające poziomowi obciążenia użytkowego) zanotowano przy obciążeniu stanowiącym około $60 \%$ siły niszczącej element odniesienia. Zniszczenie obu modeli miało charakter gwałtowny, charakterystyczny dla przebicia. Zastosowanie fibrobetonu nie spowodowało tym samym zmiany mechanizmu zniszczenia na zginający, pomimo większego wykorzystania zbrojenia podłużnego płyty. Porównując przebieg rys ukośnych widocznych na przecięciach modeli stwierdzono, iż w płycie LC-1.23-0 bis krytyczna rysa ukośna uformowała się na krawędzi słupa i biegła pod kątem $\theta=28 \div 30^{\circ}$ w kierunku górnej powierzchni płyty - jej przebieg był zatem zbliżony do obserwowanego we wcześniejszych badaniach obejmujących płyty z lekkiego betonu kruszywowego bez zbrojenia na przebicie. W przypadku elementu LCF-1.23/0.65 krytyczna rysa ukośne uformowała się również na krawędzi słupa i przecinała głowicę z fibrobetonu. Stwierdzono zmienne nachylenie rysy ukośnej, które wynosiło około $\theta=22 \div 27^{\circ}$ w obrębie głowicy oraz $\theta=12 \div 17^{\circ}$ poza nią.

Zniszczenie modeli nastąpiło przy siłach równych $700 \mathrm{kN}$ oraz $1000 \mathrm{kN}$, odpowiednio w przypadku elementów LC-1.23-0 bis oraz LCF-1.23/0.65. Ze względu na różnice w wytrzymałości na ściskanie betonu lekkiego, jak również pewne odchyłki położenia zbrojenia głównego od wartości normalnych, dokonując oceny skuteczności proponowanego rozwiązanie rozważono nośności standaryzowane. Wprowadzenie stosunkowo niewielkiej głowicy (o wysięgu około $1,25 \mathrm{~d}$ poza krawędź słupa) a także zastosowanie dolnego zbrojenia uciągającego $\mathrm{w}$ formie prętów odgiętych umożliwiło zwiększenie nośności na przebicie o około $36 \%$ względem elementu odniesienia, wykonanego w całości z lekkiego betonu kruszywowego. Wyniki przeprowadzonych badań eksperymentalnych wykazały, iż ukryte głowice z fibrobetonu mogą stanowić alternatywę dla tradycyjnego zbrojenia na przebicie. Zaproponowane rozwiązanie polegające na układania fibrobetonu wyłącznie w strefie podporowej jest zdaniem autorów możliwe i łatwe do wykonania w warunkach budowy. Ponieważ głowica obejmuje jedynie połowę grubości płyty, nie utrudnia ona późniejszego ułożenia zbrojenia głównego. Skuteczność głowicy mogłaby być prawdopodobnie większa, gdyby zwiększono jej rozmiar, jednak ocena prawdziwości tej tezy wymaga dalszych badań eksperymentalnych. 